\title{
A Study of Media Impact on Public Opinion Regarding Performance Enhancement in Major League Baseball
}

\author{
Jared W. Rutecki ${ }^{1}$ and Gregory W. Rutecki ${ }^{2, *}$ \\ ${ }^{I}$ Web Producer, Columbus Dispatch Columbus, Ohio 1028, S. Washington Ave. Columbus, OH 43206, USA \\ ${ }^{2}$ Medicine Division of Nephrology University of South Alabama, 2451 Fillingim Street, Mastin Building, Room 503, USA
}

\begin{abstract}
From 1986-2006, allegations of performance enhancement in sport exploded from a barely acknowledged phenomenon, in venues like bodybuilding and professional wrestling, to a widely publicized issue through professional baseball. For Americans, baseball is identified as the National Pastime and thereby contributes to what has been characterized as America's civil religion. News magazines, such as Sports Illustrated, Newsweek and Time, have become outlets for setting public agendas on many topics, including steroids and fair play in athletics. Through content analysis, this study associated the agenda setting effects of magazine coverage of performance-enhancement in professional baseball. Frames characterizing the issue were determined. The relationship between coverage of implicated drug use and public opinion was explored through Gallup Poll results. The data suggest that baseball is a reliable culture-reflector for American society and that steroid use and performance enhancement have become an important social issue-with ramifications extending beyond sport.
\end{abstract}

Keywords: Baseball, culture, agenda setting, performance-enhancing drugs, steroids, framing.

\section{INTRODUCTION}

The phenomena of agenda setting, priming, and framing are accepted neologisms, characterizing the media's attempts to shape public opinion. Agenda setting has been identified as one of the two most cited theories in mass communication $[1,2]$. Through dynamics inherent in these three interrelated activities, media determine which subjects are presented to their audience, how content is placed into context through cultural "frames", and ultimately, whether topics are affirmed or rejected by the public.

Recently, media attention has been directed towards the interface between sports and performance-enhancement, especially in baseball. Explicit public attention directed towards baseball is not limited to contemporary America. Baseball has received print media attention since the Nineteenth Century and has relied on prominent spokespersons like Mark Twain and Jacques Barzun [3, 4]. As a result, the game of baseball has been considered a valuable reflection of nationally shared social values and myths. Thus, for many Americans, baseball is more than a game. In this expanded role, the sport may reflect America's prevailing ethos-once described as "congruence with the American value system"- contributing to what may be a shared civil religion $[5,6]$. Recent controversy engendered by performance enhancement in sport has crystallized as an example of "cheating," inconsistent with Americans' sense of fair play. This has been summarized in concept by Murray who said,

*Address correspondence to this author at the Medicine Division of Nephrology University of South Alabama, 2451 Fillingim Street, Mastin Building, Room 503, USA; Tel: 251-470-5843; Fax: 251-471-7120;

E-mail: gregoryrutecki@usouthal.edu
"We're trying to find out who has the finest combination of talents, dedication, and the virtuous perfection of those talents. The point of sport is to show those physical and moral gifts and reward them; a drug that affects those destroys that relation between the virtuous and physical" [7].

Denham authored 4 studies on agenda setting through media coverage of steroid use in sports [8-11]. He described the cultural climate of the 1980 s as generally opposed to performance-enhancement. Sports Illustrated cover stories set an agenda opposing steroid use preceding the Anabolic Steroid Control Act (1997). Denham also identified health frames for steroids in relation to Lyle Alzado's cancer [11]. His data demonstrated a correlation between Sports Illustrated content, agenda setting, and various frames, including those related to health.

"Because adolescents frequently idolize professional

athletes...they might be inclined to experiment with

the drugs professionals have been known to use. They

also may develop inaccurate perceptions of health risks.."

The current era lends itself to further study regarding the social dynamics of agenda setting and framing in regard to baseball and performance enhancement. It may be that media agendas and public opinion will ultimately influence acceptance, rejection, or legalization of drug use in athletics. Gallup Polls have included specific questions gauging public opinion on steroids and other drugs utilized to enhance athletic performance. This study will apply content analysis of print media coverage in the context of alleged performanceenhancing drug use in professional baseball, contrasting it 
with other athletic venues. It will attempt to determine whether agendas and frames presented by the media correlated with public opinion. In addition, analysis will address whether baseball continues to reliably reflect America's values, especially in relation both to other sports and to performance enhancement in general.

\section{Background: Baseball, Social Issues, Media Agenda- Setting, and Frames}

It may be inquired whether publicized issues affecting society and sport, for example, integration, have ever been amenable to agenda setting, priming, and media framing. For example, it has been argued that Jackie Robinson's integration into professional baseball was a widely imitated milestone in the American History of Civil Rights [6]. In 1947, his integration preceded the historic Brown v. the Board of Education ruling by the United States Supreme Court (1954). The ruling was the end of legalized segregation, but baseball had already crossed that "Rubicon." Since there was also evidence to suggest that Branch Rickey's and Robinson's non- violent template later informed the Civil Rights movement $[6,12]$. study of media content and consequent broader social responses to "Baseball's Grand Experiment" are still pertinent today. The Robinson-Rickey example has been cited as "a model of peaceful transition through militant confrontation, economic pressure, and moral suasion" [12]. Furthermore, it has been claimed that the subsequent Civil Rights movement "understood the effectiveness and impact of Jackie's nonviolent disposition" and closely imitated it [6].

Gauging the interaction between the media in manipulating prevailing social attitudes towards baseball's integration prompts a retrospective content analysis of media agenda setting during that time [13]. Facts uncovered may reveal "ideology, assumptions, values, and perceptions of that era." Journalistic pieces demonstrated a spectrum of agendas, primes, and frames. The Pittsburgh Courier, an AfricanAmerican newspaper, was proactive in setting an agenda for integration, framed by an egalitarian ethos. Blacks served their country in World War II and deserved equal opportunities in professional sports $[14,15]$. The Sporting News varied in its enthusiasm for the integration experiment. In August 8, 1942, it urged caution in pursuing race issues-framed in the damage it might do to the "Negro Leagues" [16]. On November 1, 1945, editorialists commented, "the attention which the signing of Robinson elicited in the press around the country was out of proportion to the actual vitality of the story" [17]. Conversely, on August 21, 1946, praise for Robinson's skills were summarized, "What can't he do except eat in the dining room at the Waldorf"? [18]. Since the concepts of agenda setting, priming, and framing were an anachronism then, whether the media impacted the outcome was likely, but remains conjectural. Measuring the potential impact of media agenda setting however, is possible today in the field of sports as demonstrated by Denham. Scientific methods have evolved.

\section{Performance Enhancing Drugs and Athletics}

What follows is an arbitrarily abbreviated history of performance-enhancing drugs in sport only pertaining to the goals of this study. It focuses primarily on events relevant to recent print media coverage of baseball. There are other sources concentrating on broader themes engaging performance-enhancing drugs and sports [19-21].

The controversy connecting performance-enhancing drugs to sports arguably achieved generalized coverage through Ben Johnson, an Olympic sprinter. He was stripped of an Olympic gold medal, earned when he bested American Carl Lewis in the 100-meter dash in South Korea in 1988. He later tested positive for performance-enhancing drugs [22]. Expanded media coverage of this international event, coupled with implications of "cheating," made performanceenhancing drugs in sport public. Arguably, for the first time in America, the use of performance-enhancing drugs in sport became a controversial issue outside the confines of professional bodybuilding, wrestling, and cycling.

Next, Lyle Alzado implicated lifelong steroid use as the etiology for his brain cancer. His announcement was made on the television news program "First Person" as well as in a cover article for Sports Illustrated. Denham demonstrated the agenda setting effects of Alzado's personal admission [8]. Alzado's allegation of "cause and effect" between his steroid use and cancer set a media agenda for steroids and health. In fact, the media applied frames taken directly from Alzado's words. Although Johnson and Alzado's cases are not examples from baseball, as two of the first high-profile examples of performance-enhancing drug use in sports, they are critical to understanding the climate in which baseball's performance-enhancing drug scandals occurred.

Allegations of steroid use in Major League Baseball led to a widely publicized Congressional inquiry. On March 17, 2005 , baseball players and corporate executives were summoned to Congress to testify in regard to alleged performance-enhancing drug use in Major League Baseball [23]. The notoriety of Congress' action implied significant civil importance. Controversy was further disseminated through two books critical of steroid use. The first was Juiced by Jose Canseco, a former player claiming firsthand knowledge of the drugs in question. The second, Game of Shadows by Lance Williams and Mark Fainaru-Wada, offered in-depth analysis. Through years of investigative reporting, the two San Francisco Chronicle, Sports Illustrated, and ESPN reporters alleged performance-enhancing drug use by Barry Bonds through "BALCO." This abbreviated history provides background for a more specific study that follows in this paper.

\section{A Review: Agenda Setting, Priming, and Framing}

McCombs and Shaw initially identified the concept of agenda setting during political study, "The Agenda Setting Function of Mass Media" [24]. Their research uncovered specific topics covered by media and connected them to a public interest agenda. Agenda setting has been validated in more than 350 empirical studies [1]. It is a pivotal theory explaining how media create issue salience for the public [25]. McCombs and Reynolds observed, "Although many issues compete for public attention, only a few are successful at reaching the public agenda" [26]. The media's job is to inform the public regarding issues not experienced by them first hand. Steroids and performance-enhancing drugs are one example. In order for the public to engage the implications of performance-enhancing drugs in sports, the media 
must identify the relevant issues for the audience and establish their level of importance.

First, the public is alerted to relevant issues through increased media coverage. Then priming takes place as part of agenda setting within the framework of agenda setting per se. "Priming occurs when news content suggests to news audiences that they ought to use specific issues as benchmarks for evaluating the performance of leaders and governments. It is often understood as an extension of agenda setting" [27]. Although the concept of priming was developed in the context of politics, it is a non-specific media phenomenon. Priming also implies the public cannot process infinite volumes of media information. The public receives information on issues of public salience. The more relevant and uncertain an event, the greater likelihood media consumers will require issue orientation [26]. This framework exists as first-level agenda setting, whereby the media informs the public regarding issues of importance. Second-level agenda setting occurs when the media frames public perception. The agenda is then set through a process of issue priming directed at the public.

An idea intimately related to agenda setting is framing. McCombs and Shaw observed, “...priming and framing should be viewed as natural extensions of agenda-setting" [2]. McLeod, Kosicki and McLeod explain the impact of framing by stating, "Consideration of framing effects on audiences has become an important and lively research area. A key theoretical concern is that news reports can alter patterns of knowledge activation (these authors' emphasis)" [28]. In framing, media prioritize what is important in a particular news cycle and frames selected potentially shape public opinion on the issue.

If agenda setting functions as intended, a change in public opinion should be demonstrable. Whether agenda setting succeeds can be demonstrated, theoretically at least, through survey research. For example, polling organizations such as Gallup have been cited as one measure of opinion change [29]. Researchers can demonstrate a shift in public opinion by measuring media coverage and consequent attitude shift. Agenda setting functions of mass media can therefore be quantified. Data has generally verified that prominent media can set agendas across countries and platforms through salience, framing, psychological, and sociological patterns [30]. Sungtae-Ha's research also suggested that public agendas correlated with the volume of media coverage and that Gallup polling accurately measured agenda change. "In professional sports, the media agenda is set by sports news and broadcasts" [30]. Studies have also demonstrated agenda setting related to sports and news coverage. In fact, agenda setting employs polling data as a measure of public opinion. McCombs and Shaw utilized polling data compared to rank order correlations in an effort to demonstrate agenda setting [24]. Funkhouser found a strong correlation between media coverage and public agendas strengthening the theory and and contingent impact of agenda setting through polling results [31]. Polling organizations, like Gallup, can be aggregated to measure shifts in public opinion as a consequence of media coverage [32].

\section{METHODS}

The Hypotheses proposed for content analysis were:
H1: Increased coverage of performance-enhancing drug utilization in sports by selected print media (Sports Illustrated, Time, \& Newsweek) will correlate with public opinion as measured by Gallup Polling.

H2: Of specific sports mentioned by print media in articles addressing performance-enhancing drug use for Americans, baseball continues to be prominent.

RQ1: How are frames utilized throughout coverage addressing performance-enhancing drugs and sport?

This study's design was comprised of magazine reviews of specific content inclusive of dates January 1, 1986December 31, 2006. The articles were selected from three magazines representative of the largest distributions within their respective categories: Time, Newsweek and Sports I1lustrated. According to the Magazine Publishers of America, Time's circulation in 2006 was $4,082,740$ and ranked $8^{\text {th }}$; Newsweek was $3,130,600$ ranking $16^{\text {th }}$. McComb's and Shaw's exploration of agenda setting functions of mass media recognized Time and Newsweek as 2 of the most influential magazines in this regard. Studies in Mass Communication after 1972 have accepted this valuation that Time and Newsweek drive public and media agendas. Sports Illustrated has the largest circulation as a sports publication during the period of study. Its circulation in 2006 was 3,280, 630 , the highest for a sports magazine.

Articles selected were coded. Through content analysis, data were compared to dates of significant performanceenhancing drug allegations, including those involving Ben Johnson, Lyle Alzado and the BALCO steroid controversy involving Barry Bonds and Jason Giambi, as well as others. Any related incidents were reviewed for relevance. The starting date for study (1-1-86) was temporally proximate to publicized events relevant to the steroid controversy in sports (January 1, 1986 was 18 months prior to the first "highprofile performance-enhancing drug story" involving Ben Johnson). Performance enhancing drug articles implicating use in major sports were a rarity prior to Ben Johnson's publicity in 1986. Alleged performance enhancement by the East German Women's Olympic teams and San Diego Chargers' of the 1970s were not chronicled in detail until after Ben Johnson. It was determined that an interval of 18 months prior to the initial publicity surrounding Ben Johnson was reasonable. The ending date of 2006 represented the final year Gallup conducted a public poll on performanceenhancing drugs and athletics. Articles from 1986 through 1995 were selected from the Reader's Guide to Periodical Literature. These articles were chosen from topic headings such as: "steroids, performance-enhancing drugs, blooddoping and drugs in sports."

Each article containing a reference to performanceenhancing drug use was included in the census. Some articles were coded from microfilm. While blood doping is not indicative of a performance enhancing "drug" per se, the activity may be associated with other, concurrent performance enhancing drug use, so blood doping was included in search parameters. The sample acquired from 1996 to 2006 utilized the same search parameters, but articles were ultimately selected from EBSCO Search Premier because peri- 
odicals relevant to this study were archived therein. EBSCO does not include stand-alone photographs in their directory, so photographs were not included in the census.

Articles were coded as briefs (less than 1 page), features (1 page or greater in length), infographics, editorials and "other categories." In order to verify reliability of the articles selected from either EBSCO Search Premiere or the Reader's Guide to Periodical Literature, articles identified from 1996 through 2006 on EBSCO were compared to those obtained from the Readers' Guide to Periodical Literature. Of 257 articles located by EBSCO through search terms "steroids" and "performance-enhancing drugs," 205 articles were also found in the Readers' Guide to Periodical Literature, a reliability index percentage of $96.69 \%$. This number might have been higher if the Readers' Guide to Periodical Literature indexed every article included as part of a final product. As an example, a cover story about steroids might contain articles written by more than one author. The Readers' Guide to Periodical Literature might only list the results as a single article rather than indexing each separately. However, every date identified by either search engine matched. Finally, articles selected by EBSCO also exactly matched Readers' Guide to Periodical Literature, demonstrating that the print guide classified articles in the same manner as the Web database.

Sports Illustrated was chosen as the primary source magazine for study since it had the largest print circulation, as a specific sports publication, during the study period. The circulation statistics of the three selected magazines were discussed earlier. The three magazines, with high levels of market penetration also provide broader cultural access, thereby including individuals who may not access any "primary" sports media sources. Therefore, the media penetration achieved by the latter 2 magazines suggested that they might influence broader public awareness of sport and performance-enhancing drugs.

The coding protocol was based upon a previous protocol used by Denham [9]. Certain materials were deliberately excluded from analysis. Articles pertaining to corticosteroids were ignored. While corticosteroids are structurally related to anabolic steroids, they are used to treat allergic reactions and respiratory conditions (asthma), and for the most part, do not provide performance-enhancing advantages. An exception to this proposition may be cycling, however [21, 33]. Other articles about asthma, for instance, were located through EBSCO search as a result of corticosteroids utilized in the treatment of asthma. Since there was minimal evidence for The coding system also concentrated specifically on drug use by human competitors. Some competitive events, for example horse racing, have a history associated with banned performance-enhancing products [34]. Therefore, animal sporting events were also excluded.

Certain types of human athletic competition were excluded also. Sports "entertainment" (i.e. professional wrestling) has had a long history of alleged performanceenhancing drug use [35]. Any advantages gained by football or baseball players through anabolic steroids may be more "quantifiable," especially when compared to wrestlers who ostensibly compete in "scripted" contests. For similar reasons, professional bodybuilding was also excluded. While the results in bodybuilding may not be "scripted," activities are more difficult to quantify and less generalizable to a broader public and sporting audience.

The unit of analysis was the article. The coding system identified date, magazine, article type, number of pages, specific sport, alleged drugs involved, and a number of other variables. Variables included: whether the article was a feature or a brief and whether the article was coded for editorial and info-graphic content (e.g. freestanding charts and cartoons). The length of the article was subdivided into eighths of a page since that is the unit of division utilized by the EBSCO search engine. Magazine, article type, sports, and drugs were nominally identified variables. Any mention of health, sport integrity, legality, and children's issues (a health frame) were also coded if they appeared in articles. Each article might contain every frame, but each article utilized in the census contained no less than one frame. The health frame identified articles that discussed or examined the health impact of performance enhancing drug use on athletes. An example of the health frame would be a Sports Illustrated article from 2003 "Body of Evidence." The articles were also coded as to whether or not they were cover stories. The research will compare the amount of coverage directed at sports and performance-enhancing drug use, and it will compare data with specific Gallup Polling results (between 2002 and 2006). The main focus of each poll was different, but ultimately, each poll dealt with performance enhancing drug use in performance enhancing drug use become a major problem in sports"? The polling results were compared to the volume of media coverage as well as to specific frames applied in that media coverage.

Gallup performed the largest volume of polling regarding performance-enhancing drugs when compared to other major polling organizations. Therefore, poll data obtained from Gallup surveys were compared to results from content analysis in an effort to confirm agenda setting effects of performance-enhancing drug use taken from the three magazines' content.

Three graduate students verified Inter-coder reliability (two in journalism and one in political science) at a major state university. Ten percent of the articles were coded after random selection from a census obtained from each magazine. The results were calculated after initial coding pretest was complete. Any related variables, such as drugs and sports, were combined with other variables rather than coded separately. There were three coding slots accorded to sports and an additional three dedicated to specific drugs in each article. Categories of drugs and sports were coded with related variables in order to determine inter-coder reliability opposed to coding each separately under headings of drugs and sports. A small volume of articles involving three sports or three drugs made this adjustment necessary.

Inter-coder reliability, based on percentage agreement, ranged from a low of $81.6 \%$ for the variable of integrity (the most subjective frame studied) to a high of $100 \%$ for article, magazine, number of pages, and the legality frame. Overall inter-coder reliability for all variables was $93.9 \%$. Article number, magazine, date, pages and the variable for "BALCO" each scored $100 \%$. 


\section{RESULTS}

Two Hundred fifty-seven articles were analyzed (Tables 1 and 2). Sports Illustrated published the most articles related to performance-enhancing drugs between 1986 and 2006 $(\mathrm{n}=187)$. Newsweek and Time each published a similar, but lesser number ( $\mathrm{n}=36$ and 34 respectively). The largest number of articles from the three sources $(n=67)$ was published in 2005. Certain articles identified more than one frame associated with performance-enhancing drugs. There were also 339 sports included in the 257 articles. In terms of drug types within the sample, the ratio of anabolic steroids to human growth hormone approached seven-to-one (237/34 respectively).

H1: Increased Coverage of performance-enhancing drug utilization in sports by selected print media (Sports Illustrated, Time, and Newsweek) will correlate with public opinion as measured by specific Gallup Polling.

Allegations of performance-enhancing drug use in specific sports increased compared to previous coverage after specific "high profile" events. Former baseball Most Valuable Player Ken Caminiti publicly admitted personal steroid use and accused 50\% of players of similar practices [36]. Eight stories in the 3 target magazines addressing steroid use followed Caminiti's (2002) announcement, with 11 more the following year (2003). In 2004, the coverage nearly doubled to 28 stories. Evidence suggests that increased coverage of performance enhancing drugs followed Caminiti's public announcement. In fact, coverage of performance enhancing drug use in other sports-including cycling, track, and field-also increased after Caminiti's confession. This publicized admission from a former professional baseball player led to generalizability encompassing other sports.

The total articles chronicling performance enhancing drug use published annually was also examined. Articles published from 1987 through 1997 never exceeded 12 per magazine (the number published in 1988, the year of Ben Johnson's positive steroid test). With the exception of 1999 and 2001, each year experienced publication of a minimum of 9 articles, reaching a peak of 67 in 2005, a total from the 3 study magazines (Table 3). Public disapproval of steroid use in baseball, as obtained from Gallup results, increased each year the total number of articles increased, and decreased in 2006 , the only year in which the number of articles published by the three magazines decreased from the previous year. This pattern suggested correlation between the magazines' coverage of performance-enhancing drug use and public perception of the issue.

Table 1. Coverage of Specific Sports and Performance-Enhancing Drug use in Weekly Magazines from 1986 to 2006

\begin{tabular}{|l|c|c|c|}
\hline & Sports Illustrated & Newsweek & Time \\
\hline \hline Baseball & $104(43 \%)$ & $20(39 \%)$ & $7(39 \%)$ \\
\hline Football & $45(19 \%)$ & $7(14 \%)$ & $6(13 \%)$ \\
\hline Other & $42(18 \%)$ & $8(15 \%)$ & $9(18 \%)$ \\
\hline Track and Field & $40(17 \%)$ & $11(22 \%)$ & $7(15 \%)$ \\
\hline Cycling & $7(3 \%)$ & $5(10 \%)$ & $48(100 \%)$ \\
\hline Total & $238(100 \%)$ & $51(100 \%)$ & \\
\hline $\mathrm{p} \leq 0.05 \mathrm{df}=8$ & & & \\
\hline
\end{tabular}

Table 2. Breakdown of which Sports were Mentioned in Articles About Performance-Enhancing Drug use in Weekly Magazines

\begin{tabular}{|l|c|c|c|}
\hline & Sports Illustrated & Newsweek & Time \\
\hline \hline Baseball & $104(43 \%)$ & $20(39 \%)$ & $19(39 \%)$ \\
\hline Basketball & $5(2 \%)$ & $2(4 \%)$ & $0(0 \%)$ \\
\hline Boxing & $4(2 \%)$ & $0(0 \%)$ & $7(15 \%)$ \\
\hline Cycling & $7(3 \%)$ & $5(10 \%)$ & $7(15 \%)$ \\
\hline Football & $45(19 \%)$ & $0(14 \%)$ & $0(0 \%)$ \\
\hline Golf & $2(1 \%)$ & $0(0 \%)$ & $0(0 \%)$ \\
\hline Hockey & $3(1 \%)$ & $0(0 \%)$ & $0(0 \%)$ \\
\hline Tennis & $3(1 \%)$ & $11(22 \%)$ & $9(18 \%)$ \\
\hline Track and Field & $40(17 \%)$ & $4(7 \%)$ & $4(9 \%)$ \\
\hline Swimming & $24(11 \%)$ & $2(4 \%)$ & $1(2 \%)$ \\
\hline Other & $0(0 \%)$ & $51(100 \%)$ & $48(100 \%)$ \\
\hline Total & $238(100 \%)$ & & \\
\hline
\end{tabular}


Table 3. Breakdown of Articles About PerformanceEnhancing Drug use in Magazines by Year

\begin{tabular}{|c|c|}
\hline 1987 & 4 \\
\hline 1988 & 12 \\
\hline 1989 & 10 \\
\hline 1990 & 2 \\
\hline 1991 & 6 \\
\hline 1992 & 4 \\
\hline 1993 & 5 \\
\hline 1994 & 1 \\
\hline 1995 & 1 \\
\hline 1998 & 9 \\
\hline 1999 & 5 \\
\hline 2000 & 11 \\
\hline 2001 & 1 \\
\hline 2002 & 9 \\
\hline 2003 & 21 \\
\hline 2004 & 47 \\
\hline 2005 & 67 \\
\hline 2006 & 42 \\
\hline Total: & 257 \\
\hline
\end{tabular}

Apparent public interest in the steroid question and baseball elicited specific annual Gallup poll attention between 1998 and 2006. There were eight different polls performed over six years. Polls focused on a specific incident, but ultimately returned to the issue of performance enhancing drug use in general and potential fallout on society and the game of baseball. Importance of the topic was confirmed through an interview with Gallup editor Joe Carroll. Carroll who stated that, "The issue of performance-enhancing drug use in sports had become so noticeable that we had to gauge the public perception of the issue." In this regard, he said:

From a general standpoint, many of the questions that Gallup asks, whether on the topic of performanceenhancing drugs in sports, the President's proposals on issues like immigration or healthcare, or even the latest O.J. Simpson arrest, are asked to measure the public reaction to real world events, typically reported on by the mainstream media. Questions are asked to find out what Americans think about certain topics, and what they want their leaders to do in these matters. From my recollection, that was the case why we asked about this issue - how widespread the issue of performance-enhancing drugs is and was in baseball, what fans thought the impact on the game would be, and what fans wanted done about it [37].

Further delineation of Gallup results was obtained. Beginning in 1998, Gallup measured public opinion on the issue of performance enhancing drug use in competitive athletics. The year 1998 was also the year print coverage of the issue increased in the 3 magazines selected. In 1998, $48 \%$ of those surveyed by Gallup believed that performanceenhancing drug use was a serious issue for baseball and 78\% believed steroids had unfairly contributed to baseball's records, suggesting that they conferred an unfair advantage. The percentage of those polled believing performance enhancing drugs contributed to the records increased to $80 \%$ in 2002 when 9 articles were published. The number of articles published annually, as well as the public disapproval rating, increased from 2003 through 2005 to a high of $80 \%$. The disapproval rating decreased in 2006 concurrent with decreased total media coverage (42 articles), a year that also published fewer topical articles than 2005 (67 articles). In 2006 , the disapproval rating had dropped to $60 \%$ at the same time the number of articles about performance-enhancing drug use in athletics declined from 51 articles in Sports Illustrated (2005) to 33 (2006). These data support, but do not confirm a cause and effect relationship. A Spearman's rho applied to the relevant categories $(0.777, \mathrm{p} \leq 0.05)$ demonstrated a correlation between the factors in question.

A review of results as contained in (Table 2) also suggested that Baseball has garnered a greater volume of print media attention than other sports, at least in the context of performance-enhancing drugs. Of a total of 238 articles in

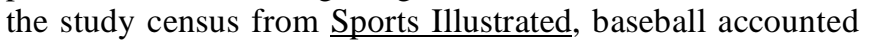
for 104 or $43 \%$ of this magazine's total. The next most frequent target sports were football $(\mathrm{n}=45 ; 19 \%)$, track and field $(n=40 ; 17 \%)$, and swimming $(n=24 ; 11 \%)$. Similarly, Newsweek and Time contained predominant content related to baseball when compared to other sports. Their figures were as follows: Baseball $(n=20$ and $19 ; 39 \%$ and $39 \%$ respectively, track and field $(n=11$ and $9 ; 22 \%$ and $18 \%$ respectively, and football $(n=7$ and $7 ; 14 \%$ and $15 \%$ respectively).

\section{Framing Performance-Enhancing Drug use in Print Media (Tables 3 \& 5)}

After 1998, multiple frames under the headings of performance-enhancing drugs and sports were applied to baseball. Frames included "integrity," "kids" (peaking in 1998 when $50 \%$ of the census articles addressing performanceenhancing drugs in sports focused on potential adverse health effects on children), "legality" (in approximately $50 \%$ of articles published during the study period), and "health." The integrity frame appeared more frequently in specific sports. Baseball (a 59.4\% incidence in 143 articles) and track (61.6\% of 46 articles) were 2 leaders for the integrity frame. This study was not designed to propose firm conclusions regarding a specific frame-driven impact on public opinion. Rather, the "frame breakdown" is intended solely for descriptive purposes. However, the preponderance of health, kids, integrity, and legality frames may support baseball's role as a "culture reflector" and may also be consistent with durable recognition as contributor to America's civil religion. Protection of children (health \& kids) and fair play as opposed to cheating (legality \& integrity) are consistent with this premise.

\section{DISCUSSION}

Content of agenda setting, priming, and framing by print media in 3 widely circulated magazines-regarding alleged and actual performance enhancing drug use in Major League 
baseball-appeared to correlate with public opinion pertaining to athletes' own admission of abuse. Although any "cause and effect" relationship between the absolute number of articles, their content or specific framing, and related public polling suggesting approval or condemnation of drug use cannot be proven, a correlation between the two is suggested by this study. Future revelations about steroid use and the manner of their media presentation to the public, in both quantitative and qualitative terms, may demonstrate evolution in society's acceptance or rejection of performance enhancement in athletics.

Table 4. Public Disapproval in Gallup Poll Results Compared with Total Articles Published by Year

\begin{tabular}{|c|c|c|}
\hline Year & Articles & Disapproval Rating \\
\hline \hline 1998 & 9 & $48 \%$ \\
\hline 1999 & 5 & $52 \%$ \\
\hline 2000 & 11 & $55 \%$ \\
\hline 2001 & 1 & $58 \%$ \\
\hline 2002 & 9 & $60 \%$ \\
\hline 2003 & 21 & $65 \%$ \\
\hline 2004 & 47 & $72 \%$ \\
\hline 2005 & 67 & $81 \%$ \\
\hline 2006 & 42 & $60 \%$ \\
\hline$($ rho $=0.777, \mathrm{p} \leq 0.05)$ & & \\
\hline
\end{tabular}

Do Gallup polling results suggesting societal disapproval of performance-enhancing drugs in athletics portend broader social implications as integration did more than a generation ago? The results may in two ways. First, athletic enhancement, either through drugs or more recently, through genetic interventions, has become a prominent subject on media and public agendas. In fact, "gene doping," defined as utilizing therapeutic advances obtained from DNA manipulation to enhance athletic prowess, has been perceived as potentially more dangerous (through a health frame) than drug enhancement. If one were to inquire whether the threat of genetic enhancement in athletics could really be this serious, deliberations of the World Anti-Doping Agency suggest that it is. The group banned "gene doping" in athletics before it was considered by any agency or implemented on any scale [38]. The con arguments and frames against gene doping are very similar to those already posed for drug enhancement. The media has also presented general aspects of genetic enhancement through reports on implementation of the Human Genome Project and cloning, 2 examples, through selected frames and consequent measurement of public reaction [39, 40]. Interestingly, public response to genetic enhancement in general, not merely in relation to athletics, mirrors public opinion rendered specifically in relation to athletic enhancement with pharmaceuticals [41]. Furthermore, debate in the arena of gene enhancement does inhabit a broader social discourse since athletics are not the only realm wherein discussion has ramifications. The difference between "therapeutic," that is, directed at a disease versus "artificial" (enhancement) applications of these technologies is generally

Table 5. Breakdown of Frames by Year

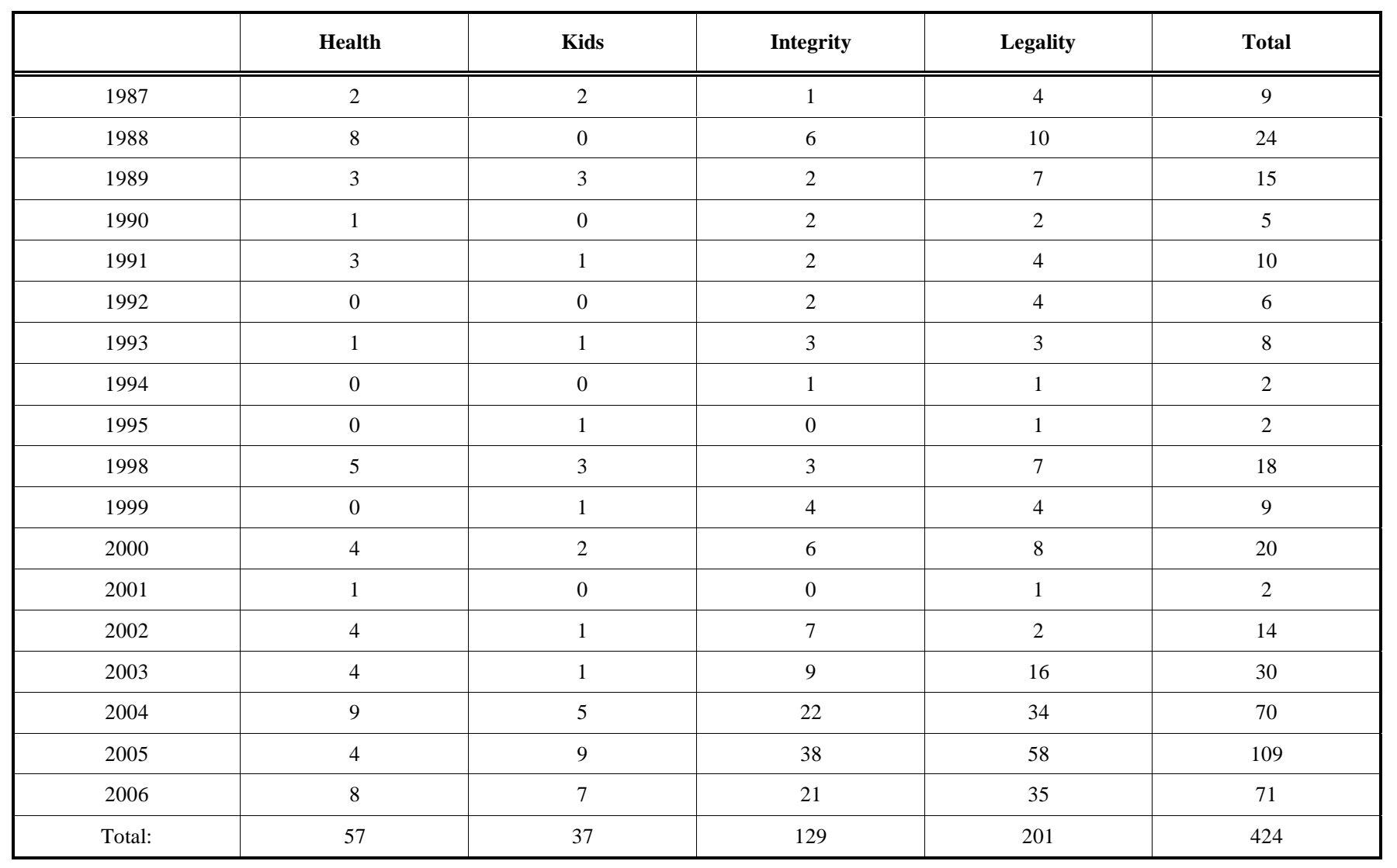


understood in contemporary debate [42]. Schneider summarized the broader controversy in sport,

"Sport is becoming a perversion and a circus...Do we want to celebrate technological achievements and surgeries on bodies that we create to do maximum performances or do we want to celebrate the human will overcoming obstacles? It is up to society to define whether it wants to see a high tech race in which the best genetic designers win or the original Olympic ethos of individuals competing with each other in their natural state. ..If commercialism pushes this (enhancement) so strongly, we lose the core values about celebrating human effort and the joy of the effort and the love of the game." [43].

There is another reason that there are broader social implications to the question of baseball and performance enhancement. Since baseball has and continues to appear to be a culture reflector for America, media frames and society's opinion on baseball-related subjects may transcend sport and mirror a more general cultural consensus. A selection of noteworthy individuals-Mark Twain, Jacques Barzun, and Bart Giamatti, for example-have intimated that the National Pastime qualifies for inclusion in rituals comprising America's civil religion [4, 6]. Furthermore, for Jacques Barzun at least, baseball has served as a "complete and self-sufficient allegory" for America and its culture-atlarge [4]. Examples from baseball's long and public history have made Twain, Barzun, and Giamatti's claims plausible. The consistency between Gallup polling specific to baseball and performance enhancement--extrapolated to human enhancement in general--suggest a degree of generalizability to America-at-large and its ethos of fair play and attitudes towards therapeutic enhancements in general.

There are limitations to this study. Only print media were included in the content analysis, and three well-circulated magazines were selected instead of other possible sources. Excluded were not only other magazine sources, for example The Sporting News and ESPN: the Magazine (which was not in circulation at the outset of this study), but also television's' opinion from sources like ESPN TV, as well as other areas like sports radio. However, the rationale for choosing the three magazines assured a sample that not only possessed a wide sports circulation (Sports Illustrated), but a broader American cultural audience as well (Time and Newsweek). This goal may not have been possible with sports-limited television reporting (such as a specific sport venue like ESPN). Also, although baseball garnered the most print media attention in the target magazines, whether that reflected prominent individual events, like the BALCO controversy, or alternatively, an important place for baseball in the American consciousness cannot be determined without further research. Precise conclusions in this regard would have required similar content analysis addressing football and track \& field, with a larger volume of periodicals. That would have been outside the scope of this project. Other sporting venues for target American audiences-such as professional football--as well as international sports, like soccer, did not receive Gallup polling attention. Therefore, expansion to these arenas would have required additional validated polling sources. Future study will be necessary to determine the influence of other sports and locations (Europe, for example) on public opinion.

Despite a wide array of performance-enhancing drugs with certain predilections for particular sports (erythropoietin and cycling), this study was predominantly focused on anabolic steroids. The frequent inclusion of "steroids" in print media articles compared to growth hormone or to other drugs emblematic of "cheating" in sports (amphetamines in cycling, for example) limited that content to the three magazines chosen for study.

Finally, some of the frames studied, the integrity one for example, had low inter-coder variability scores. Although this is an issue, this frame is more subjective and ultimately frames were included in the results only for descriptive purposes. In this regard, the overall inter-observer variability (93.9\%) was not $100 \%$.

If agenda setting by the media changes over time, so that future frames evolve in support of performance-enhancing drugs in athletics, will public opinion also change? There already have been voices in favor of legalized drug use in organized sports [44]. Iterative review of agenda setting and framing by the media, followed by trends in public opinion, may continue to furnish information relevant to the American ethos in regard to the pros and cons of various enhancement technologies.

\section{REFERENCES}

[1] Bryant J, Miron D. Theory and research in mass communication. J Commun 2004; 54: 662-704

[2] Scheufele D. Agenda setting, Priming, and Framing revisited: another look at cognitive effects of political communication. Mass Commun Soc 2000; 3: 297-316.

[3] Rubinstein WD. Jackie Robinson and the integration of major league baseball. History Today 2003; 53, Available from: www. questia.com [Cited 2009 June 18].

[4] Early G. Excerpts from: Birdland: two observations on the cultural significance of Baseball. Am Poetry Rev 1996; 4: 9-10. Available from: http://www.writing.upenn.edu [Cited 2009 June 4].

[5] Riess SA. The new sport history. Rev Am History 1990; 18: 311 25.

[6] Evans CH, Herzog II WR, Eds. The faith of 50 million. Louisville, London: Westminster John Knox Press 2002; pp. 145-66.

[7] Glazer S. Enhancement. The Hastings Center 2006; Available from: www.thehastingscenter.org [Cited 2009 January 5].

[8] Denham B. Sports Illustrated, the "War on Drugs," and the anabolic steroid control act of 1990. J Sports Soc Issues 1997; 21(3): 260-73.

[9] Denham B. Building the agenda and adjusting the frame: How the dramatic revelations of Lyle Alzado impacted mainstream press coverage of anabolic steroid use.? Soc Sport J 1999; 16:1-15.

[10] Denham B. Performance-enhancing drug use in amateur and professional sports: Separating the reality from the ramblings. Cult Sports Soc 2000; 25: 56-70.

[11] Denham B. Effects of mass communication on attitudes toward anabolic steroids: An analysis of high school seniors. J Drug Issues 2006; 36: 809-29.

[12] Tygiel J. Baseball's great experiment: Jackie Robinson and his legacy. New York: Oxford University Press 1983.

[13] Simons W. Jackie Robinson and the American mind: Journalistic perceptions of the reintegration of Baseball. J Sport Hist 1985; 12: 39-64.

[14] Deardoff DL. The Black Press played a key role in integrating baseball. St. Louis J Rev 1994; 12-4.

[15] Lamb C. I never want to take another trip like this one: Jackie Robinson's Journey to integrate baseball. J Sport's Hist 1997; 24: 177-91.

[16] Sporting News Ed: No good from raising race issue 1942.

[17] Sporting News Ed: Montreal puts Negro player on spot 1945. 
[18] McGowan L, Robinson X. Topping International Hitters, rated ready for Dodgers in '47. Sporting News 1946.

[19] Dawson RT. Drugs in Sport-the role of the physician. J Endocrinol 2001; 170: 55-61.

[20] Carstairs C. The wide world of doping: drug scandals, natural bodies, and the business of sports entertainment. Addict Res Ther 2003; 11: 263-81.

[21] Noakes TD. Tainted glory-doping and athletic performance. $\mathrm{N}$ Engl J Med 2004; 351: 847-9.

[22] Johnson W, Moore K. The Loser. Sports Illustrated 1988; 3: 20-8.

[23] Barrett T. McGwire mum on steroids hearing. CNN.com 2005. Available from: http://www.cnn.com/2005/-ALLPOLITICS/03/ 17steroids.baseball/ [Cited 2007 February 20].

[24] McCombs M, Shaw D. The agenda setting function of mass media. Public Opin Q 1972; 36: 176-87.

[25] Williams D, Maher T. Maxwell McCombs: agenda setting explorer. J Broadcast Electron Media 2006; 50(2): 358- 64.

[26] Scheufele D, Tewksbury D. Framing, Agenda setting, and priming: the evolution of three media effects models. J Commun 2007; 57: 9-20.

[27] McCombs M, Reynolds A. news influence on our picture of the world. Media Effects: Advances in theary and research, $2^{\text {nd }}$ ed. Mahwah, NJ: Lawrence Erlbaum Associates 2002; 1-18.

[28] McCleod D, Kosicki G, McLeod J. Resurveying the boundaries of political communication effects. Media Effects: Advances in theory and research. $2^{\text {nd }}$ ed. Mahwah, NJ: Lawrence Erlbaum Associates 2002; 215-67.

[29] Jones B, Baumgartner F. Representation and agenda setting. Policy Stud J 2004; 32:1-24.

[30] McCombs MA. Look at agenda setting: past, present and future. Journalism Stud 2005; 6: 543-57.

[31] Funkhouser GR. The issues of the sixties: An exploratory study of the dynamics of public opinion. Public Opin Q 1973; 37: 62-75.

[32] Shaw D, McCombs M. The emergence of american political Issues: The Agenda-Setting Function of the Press: West St. Paul 1987; pp. 1-18.
[33] Voet W. Breaking the chain: drugs and cycling; the true story. In: Potheringham W, translator. London: Yellow Jersey Press 2001.

[34] Talk of the Nation. Performance drugs and Horse Racing. National Public Radio podcast. 2005, May 5 Available from: http://www. npr.org/templates/story/story.php?storyld=4632120 [Cited 2007 May 11].

[35] Not in the Script: Too many pro wrestlers dying young. Associated Press 2007 June 30. Available from http://www.iht.com/-articles/ ap/2007/06/30/america/NA-GEN-US-Wrestlings-Shame.php [Cited 2007 August 8].

[36] Saraceno J. Baseball drops the ball on integrity. USA Today 2002: 3C.

[37] Gallup CNN, USA. Today Poll. 2002-2006. Baseball and performance-enhancing drug use. Poll questions cited 2009 August 9. Available from: LexisNexis Academic database.

[38] Gaffney GR, Parisotto R. Gene-Doping: a review of performance enhancing. Genetics and pediatric. Clin Study 2007; 54: 807-22.

[39] Tambor ES, Bernhardt BA, Rodgers J, Holtzman NA, Geller G. Mapping the human genome: an assessment of media coverage and public reaction. Genet Med 2002; 4(1): 31-8.

[40] Petersen A. Replicating our bodies, losing ourselves: News media portrayals of human cloning in the wake of Dolly. Body Soc 2002; 8: 71-90.

[41] Milner KK, Collins EE, Connors GR, Petty EM. Attitudes of young adults to prenatal screening and genetic correction for human attributes and psychiatric conditions. Am J Med Genet 1998; 76: 111-9.

[42] Frankel MS, Kapustij CJ. Enhancing humans, from birth to death and bench to clinic: The Hasting Center. Bioethics briefing book for journalists. 2008: pp. 55-8.

[43] Filipp F. Is science killing sport? Gene therapy and its possible abuse in doping. EMBO Rep 2007; 8: 433-5.

[44] Bello RJ. Faster, higher, and stronger: Why athletes should have the choice to use performance-enhancing drugs 2008; Available from: http://worksbepress.com/robert bello/1 [Cited 2009 December $15]$.

(C) Rutecki and Rutecki; Licensee Bentham Open.

This is an open access article licensed under the terms of the Creative Commons Attribution Non-Commercial License (http://creativecommons.org/licenses/by-nc/3.0/) which permits unrestricted, non-commercial use, distribution and reproduction in any medium, provided the work is properly cited. 